\title{
Records of Early English Drama: A Retrospective
}

\author{
SALLY-BETH MACLEAN
}

REED Director of Research/General Editor

The Records of Early English Drama, founded in 1976, remains a productive humanities research project, with thirty-three volumes in print and two open access research and educational websites to date. This retrospective essay reflects on the individuals who contributed to its founding and evolution; the establishment of systematic research and editorial principles for an international team of contributors; the challenges of funding a collaborative enterprise with long term goals; some of its key contributions to the field of theatre history; and the transition from a print-based series to REED Online, a multi-faceted digital enterprise. In summary, while the re-envisioning of REED as an interoperable research and educational online resource represents a major shift in editorial and publication processes, the core values of the project remain intact: to work together in interdisciplinary collaboration with like-minded partners to deliver the results of systematic research in early theatre to as wide an audience as possible in the twenty-first century.

Le Records of Early English Drama, fondé en 1976, consiste toujours en un projet fructueux de recherche en sciences humaines, totalisant à ce jour 33 volumes imprimés et deux sites web ouverts de recherche et d'éducation. Cet article rétrospectif se penche sur les personnes ayant contribué à sa fondation et son évolution, létablissement d'une systématique de recherche et de principes éditoriaux à l'intention d'une équipe internationale de contributeurs, les défis de financer un projet collectif avec des objectifs à long terme, quelques unes de ses principales contributions dans le domaine de l'histoire du théâtre, et la transition d'une publication imprimée vers le format REED Online, un projet numérique polyvalent. En effet, bien que la transformation du projet en une ressource collaborative REED de recherche et denseignement en ligne représente un changement majeur dans les processus éditoriaux et de publication, les valeurs centrales du projet demeurent inchangées: le projet vise toujours la collaboration interdisciplinaire avec des partenaires ayant la même approche afin d'obtenir des résultats de recherche systématique en histoire du théâtre, et à les rendre disponibles à un public aussi large que possible en ce vingt-et-unième siècle.

$\mathrm{T}$ he Records of Early English Drama (REED) project was founded in 1976, with its primary aim "to locate, transcribe and publish systematically all surviving external evidence of dramatic, ceremonial and minstrel activity in Great Britain before 1642." Although the focus of research was decidedly British, the founding collaborators, led by Alexandra F. Johnston, were based

1. Quoted from REED's first publication, York, ed. Alexandra F. Johnston and Margaret Rogerson, REED (Toronto: University of Toronto Press, 1979), ii. 
at universities across Canada, and the generous initial funding grant for the first decade's research and editorial work came from the Canada Council for the Arts. Johnston, a medieval drama specialist in the Department of English at the University of Toronto and an active member of the University of Victoria College's academic community, was the key figure in the location of REED's head office in Toronto. REED's editorial staff were housed for many years at Victoria College before relocating in 2009 to Suite 810 in the Jackman Humanities Building at 170 St. George Street, where the Department of English is based.

One of the first decisions taken by REED's founders was to choose a terminus ad quem for the project. The concept of a systematic collaborative effort to find and edit dramatic records was inspired by Johnston's recognition that there were a number of individual researchers who were already at work collecting documentary evidence for cities known to have biblical plays with surviving texts-York (Johnston, with her Australian collaborator Margaret Rogerson), Chester (Lawrence M. Clopper, Indiana University), Newcastle upon Tyne (J. J. Anderson, Manchester University), Coventry (R. W. Ingram, University of British Columbia), and Norwich (JoAnna Dutka, University of Toronto, and David Galloway, University of New Brunswick). ${ }^{2}$ These plays were typically studied as part of the medieval drama curriculum, although their final suppression did not actually happen until Elizabethan Protestant reforms in the later sixteenth century. Even if it had been possible to determine an agreed date when "medieval" drama ended, a strong case to move into the early modern period was made by the one Renaissance specialist in the group, David Galloway, whose work on Norwich focused on the Elizabethan and Jacobean periods when numerous professional acting companies, as well as the queen herself, visited the city. The end date of 1642, when the Puritans closed the public theatres in London at the start of the Civil War, was therefore chosen-and REED's engagement with Renaissance theatre and the Protestant Reformation, and resistance at the local level, became essential to its mandate.

Although the early participants in the REED project were typically early drama specialists, their sources of information were primarily historical rather

2. Fuller details have been published in Johnston's essay, "The Founding of Records of Early English Drama," in REED in Review: Essays in Celebration of the First Twenty-Five Years, ed. Audrey Douglas and Sally-Beth MacLean, Studies in Early English Drama (Toronto: University of Toronto Press, 2006), $21-38$. 
than literary; and so from the outset REED was interdisciplinary in its range. ${ }^{3}$ The production history of civic drama across the kingdom was already known to include the records of boroughs, trade and craft guilds, and parish and cathedral churches - the primary evidence to be edited in REED's first volumes, York (2 vols., 1979), Chester (1979), Coventry (1981), Newcastle upon Tyne (1982) and Norwich 1540-1642 (1984). However, even though an early list of projects to be promoted for new research collaborators focused on significant cities such as Bath, Bristol, and Salisbury, there was an influential alternative offered by the Malone Society, which had been publishing dramatic records organized by county rather than city. ${ }^{4}$

Richard Proudfoot, the general editor of the Malone Society volumes at the time, was an important contributor to the founding principles of the REED series. With Anthony G. Petti, author of English Literary Hands from Chaucer to Dryden $^{5}$ and a member of REED's newly-formed international executive board, Proudfoot agreed on the detailed "Guidelines for Transcription" that were henceforth to be used by both the Malone Society and REED. These guidelines were essential for the commitment to ensure that all transcriptions were presented in a uniform style and checked by someone other than the editor before publication: they have been used as consistently as is humanly possible by staff paleographers and editors ever since. The Malone Society subsequently ceded the collection of provincial dramatic records for publication to REED, and its organizing principle by county was adopted for most REED editions to follow. As a direct result, new classes of documents were identified during the following decade that have yielded illuminating results: the sometimes extensive and less familiar records of county quarter session courts; diocesan visitations

3. In the 1980s there was recognition of the need for a historian's advice on REED's executive board. The appointment of the distinguished urban historian Robert Tittler (Concordia University) to the board brought his expertise to the table and expanded REED's network significantly. Tittler in turn brought the London historians Caroline M. Barron (Royal Holloway College) and Matthew Davies (Centre for Metropolitan History, University of London) to join the board and advise on the London area collections. Tittler provided strong leadership for a decade as chair of the board from 2002.

4. For example, a founding member of REED's executive board, Stanley J. Kahrl, had edited Lincolnshire (Collections VIII, Oxford: Malone Society, 1974), and David Galloway's co-editor for Norfolk/Suffolk (Collections XI, Oxford: Malone Society, 1980/1), John M. Wasson, was keen to tackle the county of Devon for the REED series.

5. Cambridge, MA: Harvard University Press, 1977. Petti was a musicologist as well as a paleographer on the faculty of the University of Calgary. 
and ecclesiastical courts; monastic houses; and private family residences in the countryside.

The founders' expectation that systematic research across the country would uncover evidence of biblical play cycles organized in towns and cities where texts have not survived has for the most part not been realized. In retrospect, this is unsurprising: the ambitious multi-episode productions of York and Chester required a strong guild infrastructure as well as civic support that smaller towns could not muster in the period. Yet an active and diverse culture of medieval and Renaissance provincial entertainment, much of it seasonal and parish-based, can now be traced in REED's print volumes across the west of England from the Scottish border to the southernmost tip of Cornwall, including the principality of Wales. ${ }^{6}$ Because the survival rate of original documents as well as early print sources increases for the Renaissance period, there is more evidence to enrich our understanding of early modern culture at the local level and to challenge old assumptions that persist in some quarters. Recognition that traditional biblical plays continued to be performed in cities like Chester, York, and Coventry into the 1570s, while the first public theatres were being established in London, has been thoroughly documented now. Resistance to the suppression of local drama and other forms of popular entertainment by Protestant authorities is an aspect of the Reformation that extends for several decades into the seventeenth century in some parts of the country. Civil and ecclesiastical court cases provide especially vivid accounts of customs like Morris dancing that served as deliberate means of protest as well as of summer seasonal high spirits during the rise of Puritanism. One of the most striking examples of a community in deep conflict is revealed in a case that went to the higher level of the Star Chamber Court in 1608, where deponents described an elaborate summer game in May and June of the previous year that featured traditional dance, music, and pageantry that included St. George and the Dragon, as well as, perhaps more controversially, a mocking mimetic libel that had roused the ire of the target, a powerful Puritan tradesman. ${ }^{7}$ Scholars accustomed to thinking of professional acting troupes as primarily London-based have found that the extensive provincial tours undertaken, voluntarily and with some profit it

6. For an overview of REED collections, both published (thirty-three volumes to date) and forthcoming, see the REED website: http://reed.utoronto.ca.

7. Extensive records for the remarkable Hole v. White case are published in Somerset including Bath, ed. James Stokes with Robert J. Alexander, REED (Toronto: University of Toronto Press, 1996), 261-367. 
would seem, by prominent troupes like Leicester's Men, the Queen's Men, or even Shakespeare's company, the Chamberlain's/King's Men, can stimulate a reexamination of the motives and political purposes of patrons and players. As for the easy depiction of such performances occurring in rustic inn yards as a norm, REED's evidence has redirected our focus indoors, to the halls of civic authorities and private residences where weather was not a factor and conditions were more congenial for all concerned.

In 2006, several essays on various aspects of REED's impact on medieval and Renaissance studies by established scholars at arm's length from the project were published in REED in Review: Essays in Celebration of the First TwentyFive Years. REED in Review also includes a section titled "Whither REED?" with essays forecasting new directions possible for the project by several scholars at different career stages, as well as an annotated select bibliography of works titled "Using REED" by REED's former bibliographer, John Lehr. ${ }^{8}$

In recent years, publication efforts have been directed towards London, the urban centre that REED initially determined to focus away from, given its complexity and dominant place in the annals of theatre history. But provincial roads inevitably led to London, and Anne Lancashire (University of Toronto), an editor willing to tackle the voluminous corporation and guild records of the city, came forward for the purpose in the late 1970s. This enormous bibliographic and archival challenge has taken over three decades to complete, but the Civic London to 1558 collection will be published in three print volumes in spring 2015, joining two others for the area, Ecclesiastical London, ed. Mary C. Erler (2008), and Inns of Court, ed. Alan H. Nelson and John R. Elliott Jr, 3 vols. (2010). The Inns of Court, in particular, serves a specialized need for greater documentation of the art of the masque, a multimedia theatrical form that became popular in the Jacobean era at court and at the Inns where elaborate productions such as James Shirley's Triumph of Peace were mounted for the approval of royal audiences and at extraordinary cost to the participants. Publication of the Inns of Court also marked the completion of a weighty trilogy of collections from the higher educational institutions in Cambridge, Oxford, 
and London, all edited or co-edited by Alan H. Nelson (Berkeley), another long-serving member of the executive board. ${ }^{9}$

One of the important initiatives of the early years of the project was to recruit and inspire the collaborative research efforts of more editors willing to venture into the provincial archives, away from the traditional comfort zones of the British Library and the Bodleian. Johnston's dynamic leadership during this period, complemented by the active engagement of the executive board members, rallied many new scholars to the cause, all of whom participated in sharing their research in the classroom, at conferences, and through publications in print journals, including the REED Newsletter, edited for many years by JoAnna Dutka (University of Toronto). When Helen Ostovich (McMaster University) took over the Newsletter in the mid-1990s, she soon expanded its mission and readership, converting it to the peer-reviewed journal Early Theatre that continues to flourish in print and online. ${ }^{10}$

Organization for county and major city collections inspired the need for common research guidelines as well as the establishment of editorial standards for the series. ${ }^{11}$ In 1980, the REED Handbook for Editors was published by the project, primarily for members of the editorial team but it has also been used by others interested in the "Guidelines for Transcription" and the methodology developed for collaborative purposes. ${ }^{12}$ An essential component of REED's research methodology was first developed by Ian Lancashire, Johnston's coapplicant for the 1976 Canada Council grant, a colleague in the Department of English, and a founding member of the executive board. Lancashire brought his expertise as bibliographer to the project, establishing a systematic approach to supportive bibliographic research for identifying previously published dramatic

9. Both the Oxford and Inns of Court collections were completed by Nelson, in a generous act of scholarship following the death of John R. Elliott Jr.

10. Early Theatre, accessed 30 January 2015, http://digitalcommons.mcmaster.ca/earlytheatre/.

11. Essays in REED in Review by two of the first members of the Toronto editorial staff outline the development of methodology for the series: Sally-Beth MacLean, "Birthing the Concept: The First Nine Years," 39-51; and Abigail Ann Young, "'Practice Makes Perfect'; Policies for a Cross-Disciplinary Project," 52-62.

12. The Handbook was first compiled by Alexandra F. Johnston and Sally-Beth MacLean and subsequently revised by MacLean in 1990. It is freely available on REED's website in pdf format. Also available online are the "REED Palaeographic Checking Guidelines" prepared primarily for in-house editorial purposes by Abigail Ann Young. See Records of Early English Drama, accessed 30 January 2015, http:// reed.utoronto.ca/wp-content/uploads/2013/12/PalaeographicCheckingGuidelines.pdf. 
records, organized topographically, across an exhaustive range of antiquarian and scholarly books and journal articles to benefit all REED editors as well as students visiting the REED office. The results of his work, and that of graduate student and postgraduate assistants he trained in Toronto, were published in his Dramatic Texts and Records of Britain: A Chronological Topography to $1558 .{ }^{13} \mathrm{In}$ the 1980s Lancashire went on to become a Canadian leader in digital humanities, but his legacy has been maintained by others holding the staff position of REED bibliographer. For almost four decades many University of Toronto graduate students from the Centre for Medieval Studies, the Department of English and the Centre for Drama, Theatre and Performance Studies have received bibliographic training, while contributing in significant ways to the progress of research and editorial work at REED. The current bibliographer, Tanya Hagen, began her engagement with REED as a master's student to identify new records for the Derbyshire and Nottinghamshire collections through bibliographic research, but she is now more widely recognized as the lead compiler and editor of Early Modern London Theatres (EMLoT), an important open access web resource uploaded in its first phase in $2011 .{ }^{14}$

In this age of technology it is worth taking a brief retrospective look at REED's participation in the evolution of digital applications for humanities research and dissemination. During his years as REED bibliographer, Lancashire was an early advocate for the use of computers at the University of Toronto, most notably for us in the adoption of the concordance program developed in 1977 by John Bradley, now our partner in other digital collaborative ventures at the Department of Digital Humanities, King's College London. Bradley's KWIC concordance package ("COGS") ran on the University of Toronto's IBM mainframe and was used from the outset for generating computerized concordances that facilitated staff work on the glossaries that, like the indexes, have been mostly produced in-house. ${ }^{15}$ REED's collections are multi-lingual,

13. Studies in Early English Drama (Toronto: University of Toronto, 1984).

14. EMLoT, phase 1, focused on eight theatres north of the Thames. Phase 2, funded by Sally-Beth MacLean's SSHRC Insight grant, is directed to theatres south of the Thames. In October 2014, data for the early theatre of Newington Butts, the Bankside bearbaiting arenas, Hope and Swan theatres was uploaded for public access while bibliographic research continued for the Rose and the Globe. For the website, see Early Modern London Theatres, accessed 30 January 2015, http://emlot.kcl.ac.uk.

15. Bradley went on to design and implement the more sophisticated text analysis and retrieval system TACT, with Lidio Presutti at the University of Toronto. See John Bradley, “'What the Developer Saw': 
varying according to the rate of survival of earliest records but usually including Medieval and Renaissance Latin entries as well as Middle and Early Modern English and less frequently Anglo-Norman or Old French. One of the first graduate students hired in 1976 was Abigail Ann Young, who rapidly became REED's lead Latinist and paleographer until her retirement in 2012. Young developed REED's guidelines for Latin translations and glossaries, and in the past decade has created her own digital resource for broader purposes, the cumulative Anglo-Latin Wordbook, a compilation of the Latin vocabulary glossed in published REED volumes with special attention paid to the terminology of drama, music, and pastimes. The Wordbook is published on REED's website and represents years of specialized research and access to numerous sources not used by editors of the Oxford Latin Dictionary or the Dictionary of Medieval Latin from British Sources. ${ }^{16}$

Another early adopter of technology, Alan Somerset (University of Western Ontario), became an active member of the executive board and compiled the computer-generated Halliwell-Phillipps Scrapbooks: An Index in microfiche format (1979) as an extension of bibliographic support for those researching Renaissance touring entertainer records. Subsequently he acted as advisor for the development of a cumulative in-house database for tracking patrons and touring entertainers in edited REED collections, initially dubbed "Pastime" and created in Basic in 1984 by Audrey Douglas in collaboration with Sally-Beth MacLean. After some years of data entry and program migration to dBase and then Microsoft Access, MacLean and Somerset were enabled by startup grants from their two universities to begin development of REED's first open access research and educational website, Patrons and Performances. ${ }^{17}$ Two significant and ongoing partnerships were formed at that time and have proved key to REED's digital progress: Sian Meikle, now director of Information Technology Services at the University of Toronto Libraries, guided the migration of the Access data to MySQL, with ColdFusion as the middleware, and

\footnotetext{
An Outsider's View of Annotation, Interpretation and Scholarship," Digital Studies 1.1 (2009), http:// digitalstudies.org/ojs/index.php/digital_studies/article/view/143/202.

16. Oxford Latin Dictionary, ed. P. G. W. Glare (Oxford: Oxford University Press, 1982); Dictionary of Medieval Latin from British Sources, ed. R. E. Latham and D. R. Howlett, 17 fascicules (London: British Academy, 1975-2013). See Records of Early English Drama: Anglo-Latin Wordbook, http://reed.utoronto. ca/wordbook/.
}

17. Patrons and Performances, accessed 30 January 2015, http://link.library.utoronto.ca/reed/. 
Byron Moldofsky, manager of the GIS and Cartography Office, Department of Geography, led the transformation of static route mapping to the GIS provincial map now on the site. The website was launched in its first phase in $2003^{18}$ and, thanks to two Social Sciences and Humanities Research Council of Canada (SSHRC) Standard Research grants, is well-established as a dynamic medium for outreach to a wider community of users interested in the history of touring entertainers: the routes they followed across the country; the events they participated in (including the disruptive); the diversity of performance venues they used in town and guildhalls, monastic and private residences, churches, inns, and the occasional outdoor location; their patrons' landholdings, local and national offices, and family networks; and the earnings achieved on what had previously been deemed unrewarding, enforced tours during times of plague in London. Web development is not unlike theatre production: a team approach is essential. With this project, as with the bibliographical support for editors, generations of graduate students have been trained and contributed to the historical research on patrons and performance venues, analysis and entry of published REED data, and management of teamwork in a digital environment. Notable among these contributors have been Jason Boyd and John Geck, both of whom joined REED as graduate research assistants and progressed to post-doctoral leadership roles. ${ }^{19}$

A further extension of the database framework was sparked by the desire of Stephen Johnson (director of the Centre for Drama, Theatre and Performance Studies, University of Toronto) to use database technology for tracking itinerant entertainers across the English landscape in a much later period. Many of the elements required for his purposes had already been created in the REED framework; and so, with the sharing and addition of a few extra categories (e.g., for Songs \& Acts), the website for The JUBA Project: Early Blackface Minstrelsy in Britain 1842-1852 was created in partnership with REED and the Libraries'

18. MacLean and Somerset's essay, "From Patrons Web Site to REED Online," Medieval and Renaissance Drama in England 24 (2011), 25-37, outlines in more detail the stages of REED's adoption of computer technology for research, editorial and dissemination purposes.

19. Jason Boyd became digital projects manager at REED before taking up his current academic appointment as assistant professor of digital humanities at Ryerson University. John Geck has recently undertaken editorship of REED's Cambridgeshire collection. 
Information Technology Services. ${ }^{20}$ Johnson, MacLean and Beth Marquis (McMaster University), together with Meikle and Moldofsky, have recently received a SSHRC Connections grant to update and transform their websites on a new open source Drupal portal to serve as a theatre history hub of online databases that will share itineraries, patterns of movement, and primary sources for the study and understanding of touring entertainments across continents and centuries in a publicly accessible way. ${ }^{21}$

Such institutional partnerships have empowered the research dissemination of REED's work beyond the reach of the print volumes. We have been grateful over the years for the support of our first publisher, the University of Toronto Press, whose editor, Prudence Tracy, saw the potential of the series in the mid1970s and was a founding member of the executive board. However, the impetus to develop wider outreach via the Internet began in earnest in the 1990s, partly inspired by the experience of visualizing some of our data for an educational video featured in an exhibit at the Victoria and Albert's Theatre Museum (then in Covent Garden), and partly through the frustration of seeing our volumes reach only a limited number of users based at privileged universities with research libraries that could afford the high costs of the books. The need for more effective marketing strategies was obvious, and the potential of the web began to simulate other ideas for communicating REED's discoveries. The Patrons and Performances website was the cornerstone in a longer-term process to move REED more fully online. Because the press saw its primary mission as the publication of books, it proved easy to negotiate REED's ownership of electronic rights to all its products in 1998. When the opportunity arose in 2004 for REED volumes to be scanned and made available in pdf format on the Internet Archive as part of the University of Toronto Libraries' contribution, it was therefore a straightforward decision to do so, unencumbered by copyright restrictions. ${ }^{22}$

20. The JUBA Project: Early Blackface Minstrelsy in Britain 1842-1852, accessed 30 January 2015, http:// link.library.utoronto.ca/minstrels.

21. The older hub, On the Road Again: Tracking Itinerant Performance through Time (http://link.library. utoronto.ca/ontheroad/) originally featured links to REED's Patrons and Performances and Johnson's JUBA Project. Currently, Johnson's Canada West: Fringes of Show Business and Marquis's American Popular Film in Canada are also connected. The new version of On the Road Again with enhanced OpenLayers mapping for England and Wales will be uploaded in 2015.

22. All volumes published since 2005, with the sole exception of the London volumes, have also been uploaded on the Internet Archive: http://archive.org. 
REED's second digital publication followed several years later. EMLoT, in its first phase for eight theatres north of the Thames, was the product of another fruitful partnership with John J. McGavin, professor of English at the University of Southampton and now chair of REED's executive board, and with Bradley, senior analyst for Humanities Computing at King's College London. ${ }^{23}$ Not only does this website give open access to extensive annotated bibliographic data first collected in support of REED's London area collections, but it also includes a new educational feature called the "Learning Zone" created by Christie Carson (Royal Holloway College) acting as educational consultant with Christopher Hicklin, then a University of Toronto English Department graduate research assistant. The tutorial in the Learning Zone

puts forward a sequential series of timelines to highlight the kind of research that EMLoT can support. The second area puts forward a series of Other Learning Activities which can be undertaken either with a class or through independent study, illustrating the kinds of material that EMLoT contains. The final area lists Related Sites that might help to provide further context for the bibliographic information in EMLoT. ${ }^{24}$

The process of exploring the documentary history and post-1642 interpretive use of the original sources for the 1617 Riot at the Cockpit Theatre, featured in the tutorial, has prompted ideas for other educational modules that can be developed for the Patrons and Performances website as well as for the second phase of EMLoT for the theatres south of the Thames. We are currently working on a new interactive module for EMLoT that will offer students a case study, focused on the Bankside bearbaiting arenas and Hope Theatre, in the formation (and indeterminacy) of historical narrative that will provide a hands-on introduction to archival research using the open-source web-publishing platform Omeka. ${ }^{25}$

23. The partnership was funded in the United Kingdom by a generous grant to McGavin as principal investigator from the Arts and Humanities Research Council, and in Canada by grants to MacLean from the SSHRC International Opportunities Fund and Public Outreach program.

24. Quoted from the welcome page of the EMLoT Learning Zone: http://emlot.kcl.ac.uk/learning-zone/ (accessed 30 January 2015).

25. How to Track a Bear in Southwark (trackabear.library.utoronto.ca) will be developed in the spring term of 2015 with the support of the University of Toronto Libraries. Omeka (omeka.org) offers exciting possibilities for creating independent student learning projects based on REED data. 
For the past several decades, many students in Canada, the US and Britain have benefitted directly from medieval and Renaissance drama courses taught by REED editors who bring the excitement of their archival research to the classroom. Some of the most innovative ideas for teaching undergraduate and graduate courses in theatre, literature, history, paleography, and historical linguistics with REED volumes have been published in the essay collection Teaching with the Records of Early English Drama, edited by Elza C. Tiner (Lynchburg College), a former graduate research assistant. ${ }^{26}$ Yet the wider outreach of the web offers dynamic possibilities for developing digital pedagogical resources using REED data, which we are encouraging others to pursue.

The latest addition to our digital activities brings REED closer to the goal to convert most of REED's data for open access online delivery. Use of computers for transcribing and editing dramatic records before submission for checking and final production dates back to 1983 when another well-known digital humanist, Willard McCarty (King's College London), was on staff. McCarty designed a uniform ASCII code system for rendering special characters and editorial conventions on any computer at a time before Microsoft Word dominated the market and when REED editors were using a variety of wordprocessing programs (if they were using any at all). The ASCII system devised decades ago has proved robust and is still the norm for editors preparing their collections for submission to the office. However, if these collections are destined for the web in years to come, REED's editorial staff must adapt to a new digital production environment and learn to participate in the conversion of ASCII-coded text to TEI-XML. Fortunately the research and editorial strengths of the staff-led by Carolyn Black, our project manager; Patrick Gregory, senior paleographer; Arleane Ralph, copy-editor and indexer; and their research assistants - can be complemented by the digital expertise of REED's technology partners who will take the lead in directing best practices for the REED Online initiative. The newly formed Digital Advisory Committee, chaired by Bradley, is providing expert guidance for the process. ${ }^{27}$

26. Elza C. Tiner, ed., Teaching with the Records of Early English Drama, Studies in Early English Drama (Toronto: University of Toronto Press, 2006).

27. For a current list of the members of the Digital Advisory Committee, executive board, editorial team and collection editors, see REED's information website: http://reed.utoronto.ca/people/ and http://reed. utoronto.ca/print-collections-2/forthcoming/ (for the collection editors). Accessed 30 January 2015. 
In 2012, thanks to a grant from the Andrew W. Mellon Foundation, an important step was taken-with our technical partners at the Department of Digital Humanities, King's College London and the Centre for Computing in the Humanities, Ryerson University-to develop the framework for a prototype, born-digital edition for the web. The pilot project took a subset of REED research materials not yet in the familiar production process-these being the records relating to the Fortune Theatre for the Middlesex collection. We used these records and key elements of the editorial apparatus (document descriptions and notes) to develop and explore new workflows, data formats, and software. The result of a year's experimentation is uploaded for public view. ${ }^{28}$

We can now anticipate the convenience of having easy access to a complete transcribed record, such as the 1600 petition to the Privy Council to support the building of the Fortune Theatre by parishioners of St. Giles Cripplegate, especially when hyperlinked on screen with notes, glossed words, translations and document descriptions. ${ }^{29}$ Beyond such an eREED edition itself, interoperability with the EMLoT dataset will bring up the Event Record for this document, linking to detailed bibliographic and comparative information on previously published versions. There is scope for linking with the St. Giles Cripplegate parish records in REED's Ecclesiastical London collection, and with the Patrons and Performances data where, for example, the provincial touring activities of the acting companies based at the Fortune can be tracked. ${ }^{30}$ Beyond our own digital resources, we also hope to link with other external sites, such as the HensloweAlleyn Digitisation Project ${ }^{31}$ where a high quality image of the petition is available. Creating a tagged version where the people mentioned can be connected to data about them elsewhere opens up other dimensions for the kind of demographic, economic, and social history research being done at the Centre for Metropolitan History in London. But the petition also mentions locations to be tagged-the parish of St. Giles Cripplegate, the county, the proposed playhouse

28. The Fortune Theatre Records, accessed 30 January 2015, http://ereed.cch.kcl.ac.uk/.

29. Dulwich College Archive: MS I.28, f [1].

30. The Admiral's troupe reduced its provincial touring during these years but there are events for the following locations: Canterbury (25 December-25 March 1599/1600); Faversham (2 March 1601/02; Canterbury dismissal (24 March 1602/03); Faversham (2 April-29 September 1603); York (17 April 1603); and Bath (25 July 1603). The St. Giles Cripplegate parish churchwardens' accounts run from $1570 / 71$ to $1607 / 08$.

31. Henslowe-Alleyn Digitisation Project, accessed 30 January 2015, http://henslowe-alleyn.org.uk. 
itself, and the fields nearby - all of which beg to be visualized on the GIS map of the historic London area that is also in our plans for the future.

The challenges of moving REED online include the financial, as programming, training, and hiring of skilled young scholars with digital expertise is a costly and time-consuming enterprise. The first decade of REED funding was provided by the ten-year major editorial grant from the Canada Council, augmented by grants from the National Endowment for Humanities applied for every two years. However, the relative stability of the first decade was fleeting. Since 1989, REED has had to become more entrepreneurial in its determination to keep moving forward. No single funding body or institution has ensured the project's survival, although ongoing housing of the office was provided by Victoria College in the Wymilwood Building on Charles Street from 1976 to 2009 and subsequently by the Department of English in the Jackman Humanities Building. The English Department has also provided significant financial administrative assistance since 2007. Various strategies to maintain what has been lightly termed a "consortium of funds" have occupied considerable time on the part of REED's directors and board members for almost three decades: we remain deeply grateful to the University of Toronto, Victoria University, and all granting agencies, private foundations, and individuals who have responded with their support. Foremost among these continue to be SSHRC; the National Endowment for the Humanities; the Arts and Humanities Research Council, UK; the British Academy; as well as several private foundations, most notably Father Edward Jackman and The Jackman Foundation and the Andrew W. Mellon Foundation. The acknowledgments section of each REED collection details all funding received in support of the editors' work as do the "Sponsor" pages on REED's websites. Most recently, one of our former executive board members, the late Barbara D. Palmer, co-editor of the Derbyshire and Yorkshire West Riding collections, left REED a remarkably generous bequest that will help the editorial team to pursue immediate plans for moving to integrated digital publication of the series.

One of the primary reasons that all members of our executive board have been moved to endorse the re-envisioning of REED is the increasing emphasis by granting agencies on the importance of digital publication for knowledge dissemination or, in UK terms, "public impact." During the past decade, funding for digital initiatives has proved more available than for traditional print editions, and the type of collaborative partnership model that we have found so 
very stimulating and productive in our web-based projects has been similarly encouraged. Individual editors, especially those in the UK, have welcomed the move to web publication, as their own grant applications are strengthened by this commitment. The newly launched REED Pre-Publication Collections website $^{32}$ will also help to promote editorial work in progress as it makes available selected work of individual REED editors to scholars and students in draft form, ahead of their submission of data for checking and formal publication by the project. $^{33}$

As REED moves forward to publish its Civic London to 1558 volumes in print by 2015 , it is moving simultaneously to refine the workflow, TEI-XML schema, and digital infrastructure used for the Fortune Theatre Records prototype. The University of Toronto Libraries has agreed to host the open source multi-platform framework Kiln for publishing eREED collections, although we will continue to work in close consultation with our colleagues at the Department of Digital Humanities, King's College London who first developed Kiln as a server for the Fortune Theatre Records. ${ }^{34}$ The pilot county collection of Staffordshire, edited by Alan Somerset, is scheduled to be first in the eREED series, its draft files now undergoing detailed review on a Git repository hosted and maintained on a University of Toronto Libraries server. James Cummings, senior digital research specialist, IT Services, University of Oxford, first engaged with REED as a University of Toronto undergraduate volunteer years ago, but went on to a $\mathrm{PhD}$ program in medieval studies at the University of Leeds. His experience with dramatic records for his dissertation, combined with early engagement with computing in the humanities, cast him in a prophetic role during REED's twenty-fifth anniversary sessions at the International Medieval Congress, Leeds, in 2002. The paper that he delivered there, urging the adoption of XML encoding for digital editing of REED collections, was published in the REED in Review essay collection (2006). ${ }^{35}$ Although it has taken more years

32. REED Pre-Publication Collections, accessed 30 January 2015, http://reedprepub.org.

33. The pdf files of sample transcriptions with editorial apparatus have not yet been submitted for checking by REED's staff and so represent work in progress freely shared by contributing editors, with help provided by the webmaster, Peter Greenfield, editor of Bedfordshire, Hampshire and Hertfordshire and secretary to the executive board.

34. GitHub, accessed 30 January 2015, http://github.com/kcl-ddh/kiln.

35. James Cumming, "REED and the Possibilities of Web Technologies", in REED in Review, 178-99. 
to reach the stage of fully launching work on eREED editions, we are fortunate to have Cummings now acting as our expert TEI consultant.

The building blocks of Patrons and Performances and EMLoT have laid the foundation for an integrated "REED Online" hub of resources to include forthcoming eREED collections. The chart below illustrates our intention, in the first instance, to link eREED Staffordshire entries for touring companies and performance events directly with Patrons and Performances and EMLoT where fuller details of their touring habits, patrons' biographies, and performance venues (including those in the London area) are already available. The GIS mapping of provincial England and Wales on Patrons and Performances was converted from ArcGIS to OpenLayers in 2014; maps of towns and counties in previous print volumes will from now on be replaced by this GIS mapping directly linked to eREED collections. New indexing strategies for eREED Staffordshire must be developed by creating an "ontology" using the open source Entity Authority Tool Set ${ }^{36}$ that was partially tested during the Fortune Theatre Records prototype project. Establishing common terms that can be used to search within and across all eREED collections is an immediate goal, still recognizing that only when all previously published REED print collections have been converted to TEI-XML will the series be a fully dynamic web resource for researchers. It is premature to describe solutions still to be found for handling key elements such as the online interface or glossing of texts that will be aspects of REED's first interoperable edition. The year 2015 is when we will fully engage with these and other challenges. For a more detailed overview of the initial stages in eREED's development and an outline of what is to come, the White Paper published at the conclusion of the Fortune Theatre Records prototype project is available online. ${ }^{37}$

36. Entity Authority ToolSet, accessed 30 January 2015, http://eats.readthedocs.org.

37. Jason Boyd and John Bradley et al., "The Fortune Theatre Records: A Prototype Digital Edition, Records of Early English Drama (REED): White Paper," accessed 30 January 2015, http://reed.utoronto. ca/wp-content/uploads/2013/12/FortuneWhitePaper.pdf. 


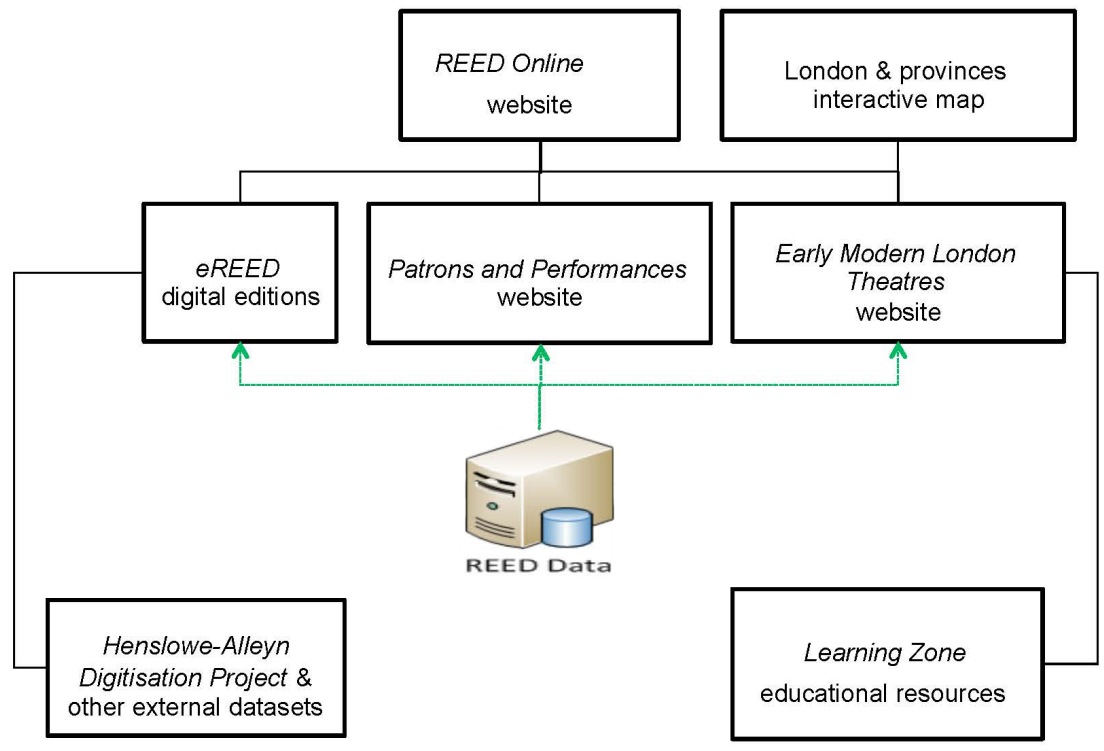

\section{Envisioning REED Online Chart}

While the re-envisioning of REED as an interoperable research and educational online resource represents a major shift in editorial and publication processes, the core values of the project remain intact: to work together in interdisciplinary collaboration with like-minded partners to deliver the results of systematic research in early theatre to as wide an audience as possible in the twenty-first century. 
